\title{
Introduction
}

Since the city is large, it needs ceremonies.*

In a revolution, said Hegel, heaven and earth are one. Commenting on the French Revolution, the German philosopher paid witness to the vitalism of the civil procession when the structure of government has collapsed, when backstage, onstage, and audience unite and act out reality together. In the revolutionary street, mass action is a play structuring reality.

Hegel's enthusiasm for creative ritual has not been shared by most moderns, for the specter of dancing processional politicians restructuring and redistributing power frightens weak and strong. The beliefs that the individual is not defined by a socially active self, that the search for one's identity takes place in the mind of the individual, not upon the streets of cities, disguise a basic fear of change. Purposeful combined action in the streets is in this view the work of a mob, of show-offs, of beasts without interior sensibilities. Civilisation or Kultur excludes mass action. The Protestant Reformation's denial of the meaningfulness of action, the Scientific Revolution's objectification of physical and social processes, and the Industrial Revolution's theft of the personal identity of work have all contributed in a general way to the modern, "civilized" view of street action. Today few

- Filarete's Treatise on Architecture, Being the Treatise by Antonio di Piero Averlino known as Filarete, ed. J. R. Spencer, I (New Haven, 1965), 44. 
social theorists consider Hegel's city more than an illusion, for even revolutions have been found to have anatomies. It is difficult to find a theorist of religion who views processional religiosity on a par with the "real religion" of the contemplative, or a student of diplomacy who takes etiquette seriously. Indeed, one (fruitful) school of social psychology views all interpersonal relations in terms of theater. ${ }^{1}$

Ritual persists, however, in the teeth of an unfriendly universe of discourse. Although some academicians resist the study of religion because "religion is a childhood disease," Japanese tea service is taught to sophisticated Occidental women, and Oriental religious forms to their men. Religious cults emphasizing mnemotic gestures spring up among social groups unsuspected of "superstition"; eminent anthropologists impressed by the ritual solidarities of less complex cultures convert to Catholicism; business managers go to Aspen, Colorado, to learn the ritual of social behavior. Some established economists even recommend returning to the ritual solidarity known to tribal cultures as part of salvation from ecological catastrophe. ${ }^{2}$ Ritual is at the base of religion, after all. Our ancestors were right when they defined religion as common behavior, and we deceive ourselves to think of it as a community of belief. A religion is a system of reverential behavior shared by a sworn community, and group authority is rooted in the normative replication of that decorum.

The survival of ritual is noticeable not only in the interpersonal and small-group realms. Political change continues to stimulate general processional activism: The parades of the Red Guards, of the Petrograd Soviets, of the French Commune, and of the Great French Revolution have all demonstrated an acceptance of the religious behavior of the past, even though the past's beliefs have been rejected. In the United States, demonstrations against the Vietnam war were as exhilaratingly creative to their participants as they were frightening and confusing to their opponents. As the war progressed, many of those who opposed the conflict but disdained demonstrations ended by taking part. This was an object lesson that something was wrong with a world view that rejected the public stage as a fitting forum to display and form beliefs and emotions, that something was askew in a concept of identity that excluded homo politicus. Humanity's need to congregate had blithely ignored the long intellectual and police campaign waged against it. In the course of these antiwar demonstrations, bemused

1. See the works of E. Goffman, including The Presentation of Self in Everyday Life (Garden City, 1959), Interaction Ritual (Garden City, 1967), and Asylums (Garden City, 1961). For critiques, see A. Gouldner, The Coming Crisis in Western Sociology (New York, 1970), 378-390, and R. Sennett, "Two on the Aisle," New York Review of Books (hereafter NYR), Nov. 1, 1973. P. Rosenberg's review of Goffman's Frame Analysis (Cambridge, Mass., 1975) suggests that Goffman has somewhat revised his earlier position; New York Times Book Review, Feb. 16, 1975, p.21.
2. R. Heilbroner, "The Human Prospect," $N Y R$, Jan. 24, 1974. The same message stressing the value of a renewed ritual vitality is in M. Douglas, Natural Symbols (New York, 1973), 19-60, and in J. Shaughnessy (ed.), The Roots of Ritual (Grand Rapids, 1973), especially the article by M. Mead, "Ritual and Social Crisis," 87-101. A sympathetic study of contemporary ritual is R. Bocock, Ritual in Industrial Society. A Sociological Analysis of Ritualism in Modern England (London, 1974). 
bystanders, the merchants of apolitical identity, lent first their names, and then for a fleeting moment their bodies, to the better reality of the political procession.

Ritual lives. It is not simply a tribal or village phenomenon, but an integral part of established urban life. This book defends that proposition. It returns to the urban culture of the medieval and early modern period to study ritual before its efficacy was challenged: ritual with no questions asked. We shall discover that conditions in the traditional European city were conducive to intense public ritual behavior, that ritual was in fact at the core of the city's identity. It played a central part in a recurrent, powerful political process by which major urban groups competitively created and asserted the primacy of their own definitions of the city's rationale and structure to their compatriots, and to the world at large. A principal task of the present work is to explain how ritual life created and resuscitated urban life, order, and values.

The best vehicle for studying ritual forms and attitudes is a city that is both a cultural and a political unit, and the Italian city-state of Florence during its republican period meets this test. An outline of its history is in order. ${ }^{3}$ Benefiting from the investiture struggle between the papacy and the Holy Roman Empire, Florence established itself as an independent commune in the twelfth century, and emerged as an important commercial center during the thirteenth. With this growth came a series of internal convulsions between the city nobility on the one side, and the non-noble families and gilds on the other, a clash terminating in the victory of the latter two parties and the establishment of the classical government of the priorate in the later thirteenth century. The history of the city from that point until the second third of the fifteenth century was dominated by strife between the "optimate" non-noble families and the propertied artisanate gathered in the gilds, with recurrent changes of regimes reflecting the increasing weakness of the republican order. In 1342 the optimates called in a foreign prince to aid them, but he soon allied himself with the lower artisanate and even with the nonpropertied, nongild proletariat (the Ciompi). Walter of Brienne failed to establish such an illegitimate one-man government, though almost everywhere else in northern Italy similar Signorias were engulfing old republican communes. In 1378 some optimate families allied themselves with these same Ciompi, and only the threat of a social revolution from below persuaded families and established gilds to unite against this proletariat and preserve the community of the possessing classes. The elitist, neoaristocratic character of the subsequent regime alone seemed capable of preserving the city's independence in the fifteenth-century world of Signorias, yet that regime prepared the way for the quasi-princely leadership of the Medici. Returning from banishment in 1434, the Medici in the following three gen-

3. The best overview of Florentine history remains

F. Schevill, Medieval and Renaissance Florence (New York, 1961). 
erations prepared the principate. Yet to the amazement of the world, optimates and gildsmen united shortly after the death of Lorenzo the Magnificent in 1492 to drive out the first family. For eighteen years, under the leadership first of the friar Savonarola and then of Piero Soderini, they maintained a refurbished republican regime. Returning to the city in 1512, the Medici were again driven out in 1527, only to return once more after the collapse of the Last Republic in 1530, claiming the city as their birthright and establishing a duchy during the same decade.

During much of this time, Florence was one of the cultural arbiters of Italy. The language of its great fourteenth-century (Trecento) writers was on its way to becoming the classical literary language of all Italians, the philology of its humanists led the way in the discovery of antiquity, and the canons of representational art established by its fifteenth-century (Quattrocento) artists would last into the twentieth century. Finally, Florence produced the leading political artists of the age, men whose brilliant reflections on the relation between the cultural and the political unity of their city make Florence not only a natural but an exciting choice for this study.

Europe possessed many types of cities; this book shows the relation between the conditions of life and ritual within one type. It first deals with the social problems generated by the political and economic structures of the city, and then examines the resulting civic cosmos as manifested in social relations and in religion at the individual, small-group, and civic levels. Finally, the exchange theory at work in this society is extracted from the behavioral sources. Once this analytical framework is established, it is possible to examine the classical commune at its ritual work: its response to the stimulus of celebration, the stimulus of foreigners, and the stimulus of danger. In the fifteenth century major changes took place in Florentine society, and we will see their impact upon classic public ritual: the movement of marginal social groups toward the center of the political stage, the Medicean challenge to traditional social and ritual organization, and the reactive but creative restructuring of ritual in the period after that family was expelled in 1494. A revolution in ritual behavior occurred during the period from 1470 to 1530 . The final chapters of this book attempt to explain these events in the context of Florentine history.

More is attempted here than a study of Florentine formalism, however, for we shall look at Florentine affairs in the light of larger questions about the nature of history, space, and behavior-with caution, but with no apologies. In the course of this first systematic study of the formal life of an urban society, a new way of periodizing the past according to behavioral epochs will be offered. Students in search of a new mind's eye for social spaces can find in these pages a perspective and approach to the urban procession and theater that may encourage them to look again at their own modern streets and churches. For those interested in behavioral processes, this book, by examining not only group but also individual dynamics on the urban stage, provides a thespo-religious approach to the problem of the 
creation and diffusion of power, authority, and status in the city. Throughout, this book asks what ought to be among the philosopher's questions: What is the relative weight of action and of thought in establishing and changing individual and group identity?

It is my belief, and the perspective of this work, that premodern urban ritual was an important means of creating, maintaining, and transforming life among populations forced to govern their own relations with foreigners, gods, and each other. The vital association of ritual with civil life declined as power and communications passed to the early modern state or dynast. The process unfolded as follows: In the Middle Ages, the urban laity shared with its clergy the task of maintaining life through ritual. They joined in prayer and procession to preserve their communities because they were sovereigns of their destinies.

Early modern absolutism witnessed the decline of local sovereignties, the integration of urban economies into world and national ones, and the outside regulation of civil precedence and order. As a result, the court assumed responsibility for maintaining life through ritual; the old rationale and sacrality of local ritual vanished, to be replaced by new meanings. Not accidentally, the attention paid to court ritual increased by quantum leaps; the peculiar modalities of the French word civilisation perhaps best suggest the thirst for a definitive ritual that contemporaries quenched by watching the absolutistic prince. ${ }^{4}$ The city in the meantime turned from processions to theater, featuring as likely as not les gestes $d u$ roi and, more recently, the spectator sports that enact territorial rites for depoliticized male citizens. The decline of public ceremonies in the cities marked the cities' political decline.

Centralized monarchies and their courts took over the ritual work of their subjects; no wonder that Protestant reformers rejected work theology in this heyday of the thaumaturgic kings. Not only had the king become the charismatic lawgiver or orator representing order to his subjects, but his

4. L. Pfandl, Philipp II (Munich, 1938), ch.8, is one of the few historians who, with cross-cultural evidence, have examined absolutistic court ceremonial in terms of its religious and sacral roots. See also $M$. Bloch, Les Rois Thaumaturges (Strassburg, 1924), and E. Kantorowicz, Laudes Regiae (Berkeley, 1946), and The King's Two Bodies (Princeton, 1957). N. Zemon Davis' superb studies of ritual constellations in sixteenth-century France are group-functionalistic in thrust. They do not examine social rites in relation to crown or political ritual or power; Society and $\mathrm{Cul}$ ture in Early Modern France (Stanford, 1975). See also her forthcoming and indicatively titled "The Sacred and the Body Social in Sixteenth-Century Lyon" (my italics), Past and Present, no. 90 (1981), 40-70. Two exchanges on works about early modern European history are especially interesting in this regard. In the first, a sociologist's book relating the character of central political structures to religious beliefs (G. Swanson, Religion and Regime: A Sociological Ac- count of the Reformation [Ann Arbor, 1967]) is critiqued by historians generally favoring local, nonpolitical emphases; "Reevaluating the Reformation: A Symposium," Journal of Interdisciplinary History I (1971), 379-446. In the second, a historian's anthropologically informed book on "magic" (K. Thomas, Religion and the Decline of Magic [London, 1971]) is criticized by anthropologist Hildred Geertz, in part for explaining ritual as personal need fulfillment rather than in reference to social and ultimate meanings, in part for disputing that things (e.g. political structures and kings) have symbolic meanings in complex societies; "An Anthropology of Religion and Magic, I, II," Journal of Interdisciplinary History VI (1975), 71-109. On the relation of courts (not cities) to the new economic systems, see I. Wallerstein, The Modern World-System. Capitalist Agriculture and the Origins of the European World-Economy in the Sixteenth Century (New York, 1974), 133-162, especially $145 \mathrm{f}$. 
everyday interaction ritual with courtiers had become sacred behavior. The life-giving procession of the medieval city or village became the equally significant daily behavior of the king. ${ }^{5}$ Reading a description of a medieval procession and then Saint-Simon's narration of a day at the court of the Sun King, one traces a common thread of concern for the welfare of the country emerging from these two different types of participatory ritual.

For all the political revolutions of modern times, we modern political pluralists have inherited the legacy of this absolutistic work ethic. Closet Jacobins in our behavioral assumptions, all but the rarest among us accept the principle, if not the distribution, of state power, presume without questioning that decorum is a virtue, and instinctively perceive the political center as the ultimate seat and stage of decorum. Ritual has become cognitively unimportant to the modern individualist-that gracious throwaway of the absolutistic state-because it is now supremely important and communicable through state agencies. The bureaucratic process, fostered at first by absolutistic state ceremonies and subsequently by nationalistic parades of soldiers and now by the television performances of high state dignitaries, is ritual at its core, a repeated exercise of political power effective because affective, a force said to be impersonal because it is rooted in the consensually accepted authority of a fascinating, righteous executive.

This historical perspective relating urban power and authority to urban ritual leads us to reexamine certain presuppositions about city space, and to arrive at some new hypotheses. Was and is the city per se antiritualistic and disenchanted, as Max Weber tended to believe, rationalized by the nature of its associations and economic activity? My approach questions this point of view, and suggests that it was through ritual that the medieval city achieved its identity, which it then lost when it surrendered its sovereignty and was subordinated to international markets and court ritual monopolies. Far from witnessing a decline of public sacred behavior, the emerging medieval city spent enormous sums on prestige economy and processional salvation. It had many of the attributes that Fustel de Coulanges ascribed to the ancient city, but denied to his own Christian towns. ${ }^{6}$

Has the city, as one school of American urban and psychological sociologists argues (Park, Goffman, Sennett), been emptied of the rich public life of yesteryear, but saturated with personal and small-group rituals because the "impersonal" nature of most urban contacts necessitates elaborate

5. The concept of ritual as life-generation is in A. Hocart, Kings and Councillors (Chicago, 1970), 33-40, 245. On the decline of urban festive life see Y.-M. Bercé, Fête et Révolte. Des Mentalités Populaires du XVIe au XVIII' siecle (Paris, 1976), 93-125. This process was slow, as was the centralization of the state. See $\mathrm{N}$. Davis's warning against oversimplification in "Deforming the Reformation," NYR, Apr. 10, 1969.

6. M. Weber, The City (New York, 1958), distinguishes between the ancient city, with its social order characterized by ritual exclusiveness, and the medieval city, where ritual social identity was absent; especially 144, 149. Partly as a result of this absence of ritual separateness, free men exchanged more easily and rationally together; see further $93 \mathrm{f}, 111 \mathrm{f}, 155$, 183, 223. F. de Coulanges, The Ancient City (Garden City, 1956), 394, believed that Christianity represented a revolt against the state, and that politics could govern man without reliance on sacred usages or the consulting of auspices or oracles. That this was not the case will be made clear in this book. 
distancing mechanisms to preserve individual privacy and identity?7 $\mathrm{Al}-$ though these thinkers follow Georg Simmel in rightly noting the importance of ritual in micro-urban life, their derivation of such behavior from the alleged impersonality of the city at large, and their inattention to the devotional roots of all gestural systems (including silence), lead them to neglect the complex fashions in which such intimate ritual did and still does relate to the personality, the honor, and the shame of the political order. ${ }^{8}$ The very urban boundaries of distance and intimacy are furnished to city dwellers by authoritative precedence-setters in the public press. At home in the city, individuals learn from modern priestesses of decorum the public behavior that is expected of them in private. Leaving that home for the beach, the football game, the demonstration, or the church, our domestic denizens understand that the street and city remain personal, not cold, and, with some original trepidation, they use the public language of signs to find, and strengthen their place in the social hierarchy of the public stage. ${ }^{9}$ We know little of the state of public ritual life in the modern city, and can scarcely judge the extent to which it builds, and transforms, our social structures; a preoccupation with the concept of impersonalism, itself an achievement of a personalistic political order, has kept modern public life from being seriously studied. Yet I suspect that public man has not declined, but has merely added the home as another locus for nationally syndicated behavior.

Was it, or is it, only among the unintegrated groups in the city that ritual has flourished, as Mary Douglas, Harvey Cox, and to some extent Max Gluckman suggest, established groups' ritual having yielded to the abstract and rational forms of communication said to be characteristic of technopolis? ${ }^{10}$ As I have indicated, I believe that, although ritual responsi-

7. See Martindale's characterization of Park in Weber's City, 22, also R. Sennett, The Fall of Public Man (New York, 1976), and the same author's critique of Goffman cited earlier, n. 1. An underlying assumption of some sociopsychologists is that private life can be sincere and spontaneous, but public life is by definition role oriented, routinized, and duplicitous. Why specific cultures make this romantic division is one of the questions posed by J. Shklar, "Let Us Not Be Hypocritical," Daedalus, Summer, 1979, pp. 1-25. An astute demolition of the idea of public routine is C. Tilly, "The Routinization of Protest in Nineteenth-Century France," and "The Web of Collective Action in Eighteenth-Century Cities," respectively Working Papers nos. 181, 74 of the Center for Researct on Social Organization.

8. Weber was aware of the importance of such socalled irrational considerations as honor in the Italian cities; City, 95, 102, 222. Scholars have given close attention to the importance of honor and shame in the Mediterranean area, emphasizing, however, the cultural more than the social sources of the phenomenon; J. G. Peristiany (ed.), Honour and Shame. The Values of Mediterranean Society (Chicago, 1966); and a special issue on social and political processes in the Western Mediterranean, Anthropological Quarterly XLII, no. 3 (1969).

9. For an absorbing comparison of a German soccer match and a religious and diplomatic ceremony, see M. Lasky, "One Nation, Divisible," New York Times Magazine, Sept. 22, 1974, 20 seq. A study of sexual territorialism in sports is A. Dundes, "Into the Endzone for a Touchdown: A Psychoanalytic Consideration of American Football," Western Folklore XXXVII (1978), 75-88.

10. Douglas, Natural Symbols, 59-76; H. Cox, The Secular City (New York, 1965); M. Gluckman, "Les Rites de Passage," in Essays on the Ritual of Social Relations, ed. Gluckman (Manchester, 1962), 35. The association of ritual first with "primitive peoples" and of late with the Western lower classes continues to bedevil the best social science long after the traditionally negative attitude of the clericoscholarly world has become history. At first Westerners thought, and primitives did; then the Western upper and lower classes both thought, the former rightly, the latter vestigially "superstitiously," if interestingly; 
bility has shifted to the state, ritual activity continues in the establishment that scorns it. As for the earlier period, the evidence in this book suggests that at a certain level of urban development toward organization, coercion, and legitimation, ritual patterns were more evident among established groups than among immigrants. In the medieval city, establishment ritual predominated, and the public ritual of urbanizing groups was inhibited because they were excluded from the streets, from organizations, and from citizenship. Ritual was not an activity of the periphery.

Finally, what is this behavior called ritual? Distinctions abound in the literature of the social sciences. Liturgy and devotional customs are different, we are told. Ceremony and ritual have been distinguished, as have secular and religious ritual. Public and private formal behavior have been the subjects of separate discourses, and scientists attempt to discover the distinction between language and speech, and between conscious and unconscious behavioral patterns. ${ }^{11}$ Yet when we examine the results of this ongoing attempt to classify formal activities, we find among historians only parochial treatises on one isolated ritual process or the other, and absolutely no consensus among social scientists as to what constitutes the essential divisions among these various distinctions. This diversity in the understanding of ritual tempts me to cast the net wide, and leads me to believe that only by interrelating these different aspects of ritual can we arrive at a general comprehension of the role of form in urban life of the premodern period. By ritual I shall mean formal behavior, those verbal and bodily actions of humans that, in specific contexts of space and time, become relatively fixed into those recognizable social and cultural deposits we call behavioral forms. The purpose of ritual, I believe, is to achieve goals; it is not obsessive or irrational, but ecologically adaptive. The mode of ritual is simultaneously

and today the lower classes are said to have a belief system ("popular culture") equally as valuable as, if sealed off from, that of the technopolis, and often from its politics. A sophisticated view of a distinct "popular culture" is given by E. Thompson, "The Moral Economy of the English Crowd in the Eighteenth Century," Past and Present L (1971), 76-136, and "Patrician Society, Plebeian Culture," Journal of Social History VII (1974), 382-405. K. Thomas' pathfinding Religion and the Decline of Magic provides a good example of the uncertainty about the "lower classes" in contemporary historical writing; the original subtitle (Studies in Popular "Beliefs"-my quotation marks) was dropped from the later paperback edition. Two brilliant studies that avoid disintegrating culture by group, and succeed in studing meaning through general societal behavior, are P. Brown, "The Rise and Function of the Holy Man in Late Antiquity," Journal of Roman Studies LXI (1971), 80-101, and "A Dark-Age Crisis: Aspects of the Iconoclastic Controversy," English Historical Review LXXXVIII (1973), 1-34.

11. Ritual as action and ritual as belief are examined by C. Crocker in "Ritual and the Development of Social Structure: Liminality and Inversion," in Shaughnessy, Roots of Ritual, 47-86. The relation between conscious and unconscious ritual is discussed in many articles edited by J. Huxley, "A Discussion on Ritualization of Behavior in Animals and Man, Philosophical Transactions of the Royal Society of London, ser. B, CCL1 (1966), 247-526. R. Firth distinguishes between communicative and acommunicative ritual in "Verbal and Bodily Rituals of Greeting and Parting," in J. La Fontaine (ed.), The Interpretation of Ritual (London, 1973), 2. J. Goody distinguishes between ceremony and ritual in "Religion and Ritual: The Definitional Problem," British Journal of Sociology XII (1961), 157 seq. The Burg Wartenstein Symposium no. 64 addressed itself exclusively to this topic: Secular Ritual Considered: Prolegomena toward a Theory of Ritual, Ceremony and Formality (Aug. 24-Sept. 1, 1974). R. Rappaport derives religious ritual viewed as communication from the sacred viewed as unquestioned beliefs; "The Sacred in Human Evolution," Annual Review of Ecology and Systematics II (1971), 23-44. 
contractual and conflictual. The result of ritual action is, finally, the smallor large-scale transformation of both the actor and the audience to the transaction.

Source limitations have admittedly forced three particular emphases. This work deals more with consciously adopted than intuitive behavior, more with group than individual activity, more with public than private display. Despite these limitations, however, the interrelated nature of different types of formal behavior remains a central thesis of this work. It is definitely necessary to break down the subject-object, viewer-artifact bias of Western studies. As Peter Brown has correctly insisted, it is impossible to understand what is happening in a work of art without giving attention to "the crowd beneath the mosaics"; ${ }^{12}$ neither can we analyze a festival or procession and ignore the audience. It is just as important to refuse an artificially imposed divine-human or religious-secular dichotomy: The behaviors of one person kneeling before the Christian image and another bowed before a secular ruler are symmetrical, and should be studied as such. In rejecting the polarizing objectifications of modern science, the student has on his side the mind-set of the urbanites he now approaches. They too recognized the public utility of private devotion and the private effects of public processions. They knew that sacred and profane acts had profane and sacred implications, that the game could be ominous and the Mass frivolous, that pomp and intention were inextricable. They were sure that no essential quality distinguished manifestations of effective form, for all took place beneath the sacred canopy.

Our subject then is that chironomic prescription of form that leads animals and man to greet in a like manner, ${ }^{13}$ moved Quintilian to recommend certain finger positions if exhorting $;^{14}$ encouraged our ancestor to bare his left shoulder while kneeling before the king if he desired to avoid death; ${ }^{15}$ and today governs the proper way to enter audience with the pope; requires the Christian, Hindu, Buddhist, or Mohammedan propitiator to assume different prayer attitudes for different ends and deities; ${ }^{16}$ and prescribes different movements to cure our different diseases. ${ }^{17}$ Our setting is a communal life where private emotions unfolded in public rituals to save the whole and each of its parts.

Formal behavior was as alive with meaning in the Renaissance as in any other culture. Yet this simple fact has long been ignored by historians,

12. P. Brown, "The View from the Precipice," $N Y R$, Oct. 3, 1974, p. 3.

13. I. Eibl-Eibesfeldt, Love and Hate (New York, 1971).

14. Institutio Oratoria (London, 1922), bk. XI, ch. 3.

15. Pfandl, Philipp II, 122.

16. T. Ohm, Die Gebetsgebärden der Völker und das Christentum (Leiden, 1948).

17. As, for example, the gestural recommendations of the Florentine physician Antonio Benivieni; L.
Thorndike, A History of Magic and Experimental Science, 8 vols. (New York, 1923-1958), IV, 588. Physical actions for dealing with the problems of pregnancy were known to the Florentines through the work of Soranus, Gynecology (Baltimore, 1956), 45-68. See also vol. III of Hippocrates, On Joints, in Loeb Classical Library (Cambridge, Mass., 1959), 201-397. P. Laín Entralgo has a suggestive study of The Therapy of the Word in Classical Antiquity (New Haven, 1970), with many references to motor therapies. 
heirs of a tradition that speaks of the period as one of individualism, in which men shattered forms to achieve "the ego revolution par excellence."18 It was a seductive message for the modern world. Despite the fact that no period of Western history was more preoccupied with correct behavior than this one, its students have preferred to follow Luther and avow the meaninglessness of what men formally did. If verbocentric historians of humanism and the arts have followed the German reformer's avocation for the Word, they have pursued the history of thought, not rhetoric. That waif of the historian's progeny has been studied not to find its meaning, but to dispute whether rhetoric had one, whether words were sincere. In the nineteenth century, Renaissance humanists were viewed as servants of tyrants; their verbal forms meant nothing. In the twentieth century Hans Baron has maintained that Florentine rhetoric was related to politics, and did have content. Now late in the century of Wittgenstein, some critics of Baron want to return to the older and primitive view of verbal and bodily formalism as "mere forms." 19

There is of course no such thing as "mere form," and inversely there never has been a factuality without form, a "politics of force" where forms were or could be ignored. ${ }^{20}$ Viewing the Renaissance individualist as antiform always has been silly science; now it is manifestly dated nineteenthcentury liberal ideology. This book will leave most questions unanswered. But as it hopes to bring historical dimension to urban and behavioral studies, so it intends to modernize the discourse among Renaissance historians.

18. The term is E. Erikson's; Young Man Luther (New York, 1962), 193. The standard work on Renaissance historiography is $\mathrm{W}$. Ferguson, The Renaissance in Historical Thought (Cambridge, Mass., 1948). For study of the "Renaissance question" see W. Bouwsma, "The Renaissance and the Drama of Western History," American Historical Review LXXXIV (1979), 1-15.

19. See, for example, P. Herde, "Politische Verhaltensweisen der Florentinischen Oligarchie, 1382-1402," in Geschichte und Verfassungsgefüge. Frankfurter Festgabe für W. Schlesinger (Wiesbaden, 1973), 161-249. More sophisticated opponents of Baron's views see humanistic rhetorical forms as evolving, but in response to the internal laws of style rather than those of politics; see, for example, J. Seigel, Rhetoric and Philosophy in Renaissance Humanism (Princeton, 1968). Others have pursued the Renaissance thinkers' insight that forms can persuade and thus change those exposed to them, but have limited themselves to verbal forms and not studied how the orators thought their bodily motions affected and transformed audiences; H. Gray, "Renaissance Humanism, The Pursuit of Eloquence," Journal of the History of Ideas XXIV (1963), 497-514. Baron's fundamental work is The Crisis of the Early Italian Renaissance (Princeton, 1966).

20. Presumably an operative concept of Machiavelli and his time; F. Gilbert, Machiavelli and Guicciardini (Princeton, 1965), 131 and passim. 


\section{Public Life in Renaissance Florence}


